\title{
RESPON PERTUMBUHAN KECOMBRANG (Etlingera elatior) PADA PEMBERIAN FERMENTASI URINE KELINCI DAN AIR KELAPA
}

\section{GROWTH RESPONSE OF KECOMBRANG (Etlingera elatior) ON FERMENTATION OF RABBIT URINE AND COCONUT WATER}

\author{
Wildan Rabbani, Arrin Rosmala*, Selvy Isnaeni \\ Program Studi Agroteknologi, Fakultas Pertanian, Universitas Perjuangan Tasikmalaya \\ Jl. PETA No. 177, Kahuripan, Tawang, Kota Tasikmalaya, Jawa Barat 46115 - Indonesia \\ *Korespondensi: arrinrosmala@unper.ac.id
}

\begin{abstract}
ABSTRAK
Kecombrang merupakan salah satu tanaman rempah di Indonesia yang sering dimanfaatkan secara tradisional sebagai bahan pencipta rasa pada makanan juga untuk obat tradisional seperti menghilangkan dahak dan batuk. Urine kelinci merupakan cairan yang mampu memberikan suplai nitrogen yang cukup tinggi bagi tanaman, hal ini disebabkan oleh tingginya kadar nitrogen yang terdapat di dalamnya. Air kelapa merupakan produk tanaman dengan salah satu zat gizi yang mempunyai kadar tinggi yaitu kalium sebesar $3120 \mathrm{mg} \mathrm{L}^{-1}$. Penelitian ini bertujuan untuk mengetahui pengaruh perlakuan fermentasi urine kelinci dengan air kelapa terhadap pertumbuhan tanaman kecombrang dan untuk mendapatkan perlakuan yang paling optimal terhadap pertumbuhan tanaman kecombrang. Penelitian ini dilaksanakan pada bulan Oktober 2020 - Januari 2021 di Screen house Program Studi Agroteknologi, Fakultas Pertanian, Universitas Perjuangan Tasikmalaya dengan ketinggian tempat 359 mdpl. Penelitian menggunakan fermentasi urine kelinci dan air kelapa. Rancangan Acak Lengkap (RAL) dengan 7 kali ulangan. Hasil penelitian menunjukkan pemberian fermentasi urine kelinci $25 \%$ menghasilkan jumlah akar paling banyak yaitu sebesar 5,2 helai. Perlakuan urine kelinci tidak berpengaruh nyata terhadap parameter tinggi tanaman, diameter batang, jumlah daun, panjang daun, warna daun dan lebar daun.
\end{abstract}

Kata kunci: air kelapa; fermentasi urine kelinci; kecombrang

\begin{abstract}
Kecombrang is one of the spice plants in Indonesia that is often used traditionally as a flavoring ingredient in food as well as for traditional medicine such as eliminating phlegm and coughs. Rabbit urine is a liquid that is able to provide a high enough nitrogen supply for plants, this is due to the high nitrogen content in it. Coconut water is a plant with one of the nutrients that has high levels of potassium at $3120 \mathrm{mg} \mathrm{L}^{-1}$. This study aims to determine the effect of fermentation treatment of rabbit urine with coconut water on the growth of the kecombrang plant and to obtain the most optimal treatment for the growth of the kecombrang plant. This research was conducted in October 2020 - January 2021 at the Screen house of the Agrotechnology Study Program, Faculty of Agriculture, Universitas Perjuangan Tasikmalaya with an altitude of 359 meters above sea level. The study used fermented rabbit urine and coconut water. Completely Randomized Design (CRD) with 7 replications. The results showed that the administration of $25 \%$ rabbit urine fermentation produced the highest number of roots, which was 5.2 strands. The treatment of rabbit urine did not significantly affect the parameters of plant height, stem diameter, number of leaves, leaf length, leaf color and leaf width.
\end{abstract}

Keywords: coconut water; kecombrang; rabbi urine fermentation 


\section{PENDAHULUAN}

Kecombrang adalah salah satu tanaman rempah- rempah di Indonesia yang banyak dimanfaatkan secara tradisional sebagai bahan pencipta rasa pada makanan di beberapa negara (Suryani et al., 2019). Selain itu, kecombrang dimanfaatkan juga untuk obat tradisional seperti menghilangkan dahak dan batuk (Sukandar et al., 2011). Tanaman kecombrang satu famili dengan Zingiberaceae yaitu tanaman rimpangrimpangan seperti jahe, kunyit, kencur, dan temulawak (Maimulyanti \& Prihadi, 2015). Kecombrang biasanya diperbanyak dengan rimpang, dan mulai berbunga 12 bulan dari semenjak ditanam (Choon \& Ding, 2017). Berdasarkan hasil beberapa penelitian kecombrang memiliki berbagai kandungan senyawa aktif seperti alkaloids, tannins, flavonoids, saponin, steroid, glycosides, minyak atsiri, dan karbohidrat (Tan et al., 2011; Askal \& Anton, 2015; Rosmala et al., 2020).

Beberapa tahun ini kecombrang menjadi perhatian peneliti dan pengusaha di bidang pertanian karena mengandung aktivitas anti bakteri dan memiliki harga jual relatif tinggi (Rosmala et al., 2020). Hal ini sejalan dengan penelitian Rusanti et al. (2017) kecombrang berfungsi sebagai anti kanker, anti bakteri dan antioksidan.
Pertumbuhan tanaman harus diperhatikan agar mendapatkan hasil produksi yang baik, salah satunya dengan pemberian pupuk organik. Pemanfaatan bahan organik untuk budidaya tanaman pertanian dapat mengurangi pemakaian pupuk kimia (Tiwery, 2014). Salah satu pupuk organik yang memiliki manfaat untuk meningkatkan kesuburan tanah adalah fermentasi urine kelinci yang juga mampu meningkatkan produktivitas tanaman (Sembiring et al., 2011).

Produksi kecombrang sampai saat ini masih sedikit karena tidak dibudidayakan dengan serius. Penanaman kecombrang masih secara tradisional dan hanya untuk konsumsi skala rumah tangga. Budidaya kecombrang belum memakai teknologi pemupukan. Pupuk organik yang unsur haranya mudah diserap oleh tanaman adalah dalam bentuk cairan. Pupuk organik cair lebih mempermudah tanaman menyerap hara dibandingkan dengan pupuk lainnya yang berbentuk padat. Pupuk cair juga memiliki unsur yang mudah terurai sehingga pemanfaatannya dapat lebih mudah dilihat (Imran, 2016).

Menurut penelitian Rosniawaty et al. (2015) pada tanaman tomat, menunjukan bahwa konsentrasi urine kelinci 3000 ppm dapat meningkatkan pertumbuhan vegetatif tanaman kakao 
yaitu berat kering tanaman, berat segar tanaman, berat kering batang dan berat kering daun, tetapi tidak berpengaruh pada pertumbuhan generatif tanaman. Salah satu produk tanaman yang dapat dimanfaatkan untuk membantu dalam pertumbuhan tanaman adalah air kelapa. Penggunaan air kelapa memberikan dampak yang nyata terhadap pertumbuhan, tinggi dan jumlah daun tanaman sawi. Berdasarkan penelitian Aulia et al. (2018) air kelapa kaya akan Natrium (Na), Kalsium (Ca), Magnesium $(\mathrm{Mg})$, Cuprum (Cu), Ferum (Fe) Sulfur (S), gula dan protein. Aplikasi Fermentasi urin kelinci dan air kelapa belum pernah diaplikasikan pada budidaya kecombrang. Aplikasi fermentasi urin kelinci dan air kelapa serta kombinasinya diharapkan dapat meningkatkan pertumbuhan tanaman kecombrang. Tujuan penelitian untuk mengetahui pengaruh perlakuan fermentasi urine kelinci dengan air kelapa terhadap pertumbuhan tanaman kecombrang dan untuk mendapatkan perlakuan yang paling optimal terhadap pertumbuhan tanaman kecombrang

\section{METODE PENELITIAN}

Penelitian dilaksanakan pada bulan Oktober 2020 - Januari 2021 di Screen house Program Studi Agroteknologi, Fakultas Pertanian, Universitas
Perjuangan Tasikmalaya dengan ketinggian tempat $359 \mathrm{mdpl}$.

Bahan-bahan yang digunakan adalah rimpang kecombrang, fermentasi urine kelinci dan air kelapa, media tanam (tanah, pupuk kandang, dan arang sekam 2:1:1), EM4 dan gula putih. Alat-alat yang digunakan adalah polybag ukuran $35 \mathrm{~cm}$ x $40 \mathrm{~cm}$, meteran, hand sprayer, cangkul, sekop, alat tulis, label, kamera, thermohygrometer, pH meter, jerigen, timbangan digital, selang, ember dan gelas ukur. Penelitian menggunakan Rancangan Acak Lengkap (RAL). Percobaan terdiri atas 5 taraf perlakuan dan setiap taraf perlakuan diulang sebanyak 7 kali sehingga terdapat 35 unit percobaan. Setiap unit percobaan terdiri dari 1 tanaman sehingga total terdapat 35 tanaman.

Pengamatan utama meliputi tinggi tanaman (cm), jumlah daun (helai), panjang daun $(\mathrm{cm})$, lebar daun $(\mathrm{cm})$, warna daun, diameter batang $(\mathrm{cm})$, panjang akar $(\mathrm{cm})$, jumlah anakan. Analisis data yang diperoleh secara kuantitatif dilakukan analisis ragam/ Analysis of Varience (ANOVA). Uji F taraf nyata $5 \%$ digunakan untuk menguji keragaman. Apabila terdapat keragaman yang nyata maka dilanjutkan dengan uji jarak berganda Duncan untuk membandingkan di antara perlakuan.

Pelaksanaan penelitian meliputi pembuatan fermentasi urine kelinci 
sebanyak 80 L yang difermentasi dalam drum berukuran 100 L. Urine kelinci difermentasi menggunakan bantuan EM4 sebanyak 4 tutup botol dan ditambahkan gula pasir sebanyak 4 sendok makan yang dilarutkan sampai homogen, kemudian drum ditutup rapat. Fermentasi urine kelinci diaduk setiap minggu sekali sampai fermentasi urine kelinci matang.

Penanaman rimpang kecombrang sebelum ditanam dilakukan perendaman terlebih dahulu menggunakan fungisida selama 60 menit kemudian ditanam pada polybag berdiameter $35 \mathrm{~cm}$. Kedalaman lubang tanam sebesar 5-10 cm. Pemupukan menggunakan fermentasi urine kelici dan air kelapa yang dilakukan 2 minggu sekali dengan dosis $25 \mathrm{~mL}$ saat tanaman berumur 2 MST, $35 \mathrm{~mL}$ saat tanaman berumur 4 MST, $50 \mathrm{~mL}$ saat tanaman berumur 6 MST, $60 \mathrm{~mL}$ saat tanaman berumur 8 MST, $75 \mathrm{~mL}$ saat tanaman berumur 10 dan 12 MST, $90 \mathrm{~mL}$ saat tanaman berumur 14 dan 16 MST.
Pengendalian organisme pengganggu tanaman (OPT) dilakukan menggunakan insektisida berbahan aktif klorantraniliprol $100 \mathrm{~g} \quad \mathrm{~L}^{-1}$. Selain menggunakan insektisida, pengendalian OPT juga dilakukna secara teknis yakni dengan cara membuang ulat kantung yang biasa menyerang tanaman kecombrang.

\section{HASIL DAN PEMBAHASAN}

\section{Tinggi tanaman dan diameter batang}

Hasil analisis sidik ragam tinggi tanaman saat berumur 16 MST disajikan pada Tabel 1 yang menunjukkan perlakuan tidak berpengaruh nyata terhadap tinggi tanaman dan diameter batang kecombrang. Menurut penelitian Djafar et al. (2013) menyatakan bahwa perlakuan POC fermentasi urine kelinci tidak berpengaruh nyata terhadap pertumbuhan dan produksi tanaman sawi yang diakibatkan oleh penggunaan konsentrasi fermentasi urine kelinci yang tidak optimal.

Tabel 1. Nilai rerata tinggi tanaman dan diameter batang kecombrang saat berumur 16 MST

\begin{tabular}{lcc}
\hline \multicolumn{1}{c}{ Perlakuan } & $\begin{array}{c}\text { Tinggi } \\
\text { tanaman }(\mathbf{c m})\end{array}$ & $\begin{array}{c}\text { Diameter } \\
\text { batang }(\mathbf{c m})\end{array}$ \\
\hline A (Kontrol) & 13,00 & 2,86 \\
B (Fermentasi urine kelinci 25\%) & 16,00 & 3,57 \\
C (Fermentasi urine kelinci 50\%) & 19,36 & 3,71 \\
D (Air kelapa 25\%) & 15,79 & 2,93 \\
E (Fermentasi Urin kelinci 25\% dan Air kelapa 25\%) & 18,57 & 2,93
\end{tabular}

Keterangan : Nilai rata-rata yang ditandai huruf yang sama pada kolom yang sama menunjukan tidak berbeda nyata menurut sidik ragam pada taraf $5 \%$. 
Hasil analisis sidik ragam pada Tabel 1 menunjukan perlakuan tidak berpengaruh nyata terhadap diameter batang tanaman kecombrang. Perlakuan C (Fermentasi urine kelinci 50\%) menghasilkan diameter 3,71 $\mathrm{mm}$, cenderung menghasilkan diameter lebih besar dibandingkan dengan perlakuan lain. Sedangkan perlakuan A (Kontrol) menghasilkan diameter 2,86 $\mathrm{mm}$, paling kecil dibandingkan dengan perlakuan lain. Kandungan $\mathrm{pH}$ tanah yang masam, serta tanaman kecombrang merupakan tanaman tahunan menjadikan pemberian pupuk fermentasi urine kelinci dan air kelapa tidak berpengaruh nyata terhadap diameter batang. Hal ini sejalan dengan penelitian Sembiring et al. (2017) bahwa pemberian urine kelinci pada tanaman tomat tidak berpengaruh nyata terhadap diameter batang.

\section{Jumlah daun dan warna daun}

Hasil analisis sidik ragam pada Tabel 2 menunjukan perlakuan tidak berpengaruh nyata terhadap jumlah dan warna daun. Berdasarkan Tabel 2, perlakuan C (Fermentasi urine kelinci $50 \%$ ) cenderung memberikan jumlah daun paling banyak. Sedangkan perlakuan B (Fermentasi urine kelinci $25 \%$ ) cenderung memberikan jumlah daun yang paling sedikit. Tanaman kecombrang yang diberikan perlakuan fermentasi urine kelinci dan air kelapa tidak berpengaruh nyata yang disebabkan oleh pengaruh genetik tanaman. Sejalan dengan penelitian Rosniawaty et al. (2015) jumlah daun tanaman kakao yang diberikan fermentasi urine kelinci tidak berpengaruh nyata akibat pengaruh genetik tanaman lebih dominan dibandingkan dengan lingkungan.

Tabel 2. Nilai rerata jumlah dan warna daun tanaman kecombrang saat berumur 16 MST

\begin{tabular}{lcc}
\multicolumn{1}{c}{ Perlakuan } & Jumlah Daun (helai) & Warna Daun \\
\hline A (Kontrol) & 2,57 & 1,86 \\
B (Fermentasi urine kelinci 25\%) & 2,14 & 2,71 \\
C (Fermentasi urine kelinci 50\%) & 3,86 & 2,57 \\
D (Air kelapa 25\%) & 2,29 & 2,43 \\
E (Fermentasi Urin kelinci 25\% dan Air kelapa 25\%) & 3,14 & 3,00 \\
\hline Keterangan : Nilai rata-rata yang ditandai huruf yang sama pada kolom yang sama menunjukan tidak berbeda \\
\multicolumn{2}{c}{ nyata menurut sidik ragam pada taraf 5\%. }
\end{tabular}

Berdasarkan data warna daun perlakuan E (Fermentasi urine kelinci $25 \%$ dan air kelapa 25\%) cenderung menghasilkan warna daun paling tinggi yaitu sebesar 3,00. Pada perlakuan A (kontrol) cenderung menunjukan adanya gejala warna kuning di minggu ke 8 sampai minggu 16 MST pada daun yang diakibatkan tidak adanya perlakuan pada tanaman kecombrang, yang mengakibatkan tanaman kecombrang kekurangan unsur N, sehingga 
mengakibatkan warna daun menjadi kuning. Pertumbuhan tanaman yang diindikasikan warna daun berkaitan erat dengan zat hara yang diserap tanaman dan jumlah air pada media yang melarutkan unsur hara tersebut (Syifa et al., 2020).

\section{Lebar daun dan panjang daun}

Hasil analisis sidik ragam pada Tabel 3 menunjukkan bahwa perlakuan pemberian fermentasi urine kelinci dan air kelapa tidak memberikan pengaruh nyata terhadap lebar dan panjang daun pada tanaman kecombrang.

Tabel 3. Nilai rerata lebar daun dan panjang daun tanaman kecombrang saat berumur 16 MST

\begin{tabular}{lcc}
\hline \multicolumn{1}{c}{ Perlakuan } & Lebar Daun $\mathbf{( c m )}$ & Panjang Daun (cm) \\
\hline A (Kontrol) & 2,57 & 2,93 \\
B (Fermentasi urine kelinci 25\%) & 3,86 & 3,86 \\
C (Fermentasi urine kelinci 50\%) & 3,71 & 5,00 \\
D (Air kelapa 25\%) & 2,71 & 2,71 \\
E (Fermentasi Urine kelinci 25\% dan Air kelapa 25\%) & 3,93 & 5,14 \\
\hline
\end{tabular}

Keterangan : Nilai rata-rata yang ditandai huruf yang sama pada kolom yang sama menunjukan tidak berbeda nyata menurut sidik ragam pada taraf $5 \%$.

Berdasarkan Tabel 3, perlakuan E (Fermentasi Urin kelinci 25\% dan Air kelapa 25\%) cenderung memberikan lebar daun yang paling lebar yaitu 3.93. Perlakuan E (Fermentasi urin kelinci $25 \%$ dan air kelapa 25\%) memberikan panjang daun 5,14 cm. Menurut penelitian Dongoran \& Sularno (2019) menyatakan bahwa pemberian air kelapa dengan dosis yang terlalu tinggi yang didalamnya terkandung auksin dan giberelin dapat menghambat proses pertumbuhan panjang daun tanaman karet.

\section{Panjang akar}

Hasil analisis sidik ragam panjang akar disajikan pada Tabel 4. Hasil pengamatan menunjukan bahwa perlakuan A (kontrol) berpengaruh nyata terhadap panjang akar.

Tabel 4. Nilai rerata panjang akar tanaman kecombrang saat berumur 16 MST

\begin{tabular}{lc}
\hline \multicolumn{1}{c}{ Perlakuan } & Panjang akar (cm) \\
\hline A (Kontrol) & $15 \mathrm{a}$ \\
B (Fermentasi urine kelinci 25\%) & $6,5 \mathrm{bc}$ \\
C (Fermentasi urine kelinci 50\%) & $4,75 \mathrm{c}$ \\
D (Air kelapa 25\%) & $6,38 \mathrm{bc}$ \\
E (Fermentasi Urine kelinci 25\% dan Air kelapa 25\%) & $9,25 \mathrm{~b}$
\end{tabular}

Keterangan a : Nilai rata-rata yang ditandai hurup yang sama pada kolom yang sama menunjukan berbeda nyata menurut sidik ragam pada taraf $5 \%$ 
Berdasarkan data rata-rata panjang akar, perlakuan A (kontrol) memberikan panjang akar tanaman paling panjang yaitu sebesar $15 \mathrm{~cm}$, dibandingkan dengan yang diberikan perlakuan fermentasi urine kelinci dan air kelapa. Namun perlakuan E (Fermentasi Urine kelinci 25\% dan Air kelapa 25\%) menghasilkan panjang akar yang sama dengan perlakuan $B$ (Fermentasi urine kelinci 25\%), dan D ( Air kelapa 25\%). Hal ini karena kandungan $\mathrm{pH}$ unsur hara yang basa dan unsur hara yang ada di dalam tanah sudah cukup menyebabkan laju pertumbuhan panjang akar tanaman kecombrang terhambat. Pertumbuhan tanaman ditentukan oleh penyerapan unsur hara makro dan mikro dari larutan nutrisi yang tersedia. Penyerapan unsur hara dipengaruhi oleh keadaan $\mathrm{pH}$ larutan nutrisi. Nilai $\mathrm{pH}$ menentukan ketersediaan berbagai elemen untuk tanaman. (Subandi et al., 2015).

\section{Jumlah akar}

Hasil analisis sidik ragam menunjukkan bahwa perlakuan fermentasi urine kelinci dan air kelapa memberikan pengaruh nyata terhadap parameter jumlah akar saat berumur 16 MST.

Tabel 5. Nilai rerata jumlah akar tanaman kecombrang pada 16 MST

\begin{tabular}{lc}
\hline \multicolumn{1}{c}{ Perlakuan } & Jumlah akar \\
\hline A (Kontrol) & $4,8 \mathrm{a}$ \\
B (Fermentasi urine kelinci 25\%) & $5,2 \mathrm{a}$ \\
C (Fermentasi urine kelinci 50\%) & $2,8 \mathrm{ab}$ \\
D (Air kelapa 25\%) & $1,8 \mathrm{~b}$ \\
E (Fermentasi Urine kelinci 25\% dan Air kelapa 25\%) & $4,8 \mathrm{a}$ \\
\hline
\end{tabular}

Keterangan $^{a}$ : Nilai rata-rata yang ditandai hurup yang sama pada kolom yang sama menunjukan berbeda nyata menurut sidik ragam pada taraf $5 \%$.

Tabel 5 menunjukkan bahwa perlakuan B (Fermentasi urine kelinci 25\%) memberikan jumlah akar paling banyak, yaitu sebesar 5,2 helai, sama halnya dengan perlakuan E (Fermentasi urine kelinci $25 \%$ dan air kelapa 25\%) yaitu sebesar 4,8 helai, dan perlakuan $\mathrm{A}$ (kontrol) yaitu sebesar 4,8 helai. memberikan jumlah akar paling banyak di antara perlakuan lainnya, di mana nilai jumlah akar paling banyak dihasilkan oleh perlakuan B (5,2 helai). Sedangkan perlakuan D (Air kelapa 25\%) memberikan jumlah akar (1,8 helai), paling sedikit dibandingkan dengan perlakuan lain. Menurut Sembiring et al. (2017) yang menyatakan bahwa pada hasil fermentasi urin kelinci juga dapat mempengaruhi pada proses penyerapan unsur hara pada tanaman. Suhu pada proses penguraian tidak sesuai, sehingga organisme yang masih ada pada urin 
kelinci tidak semuanya mati, dan menyebabkan nutrisi sulit untuk diserap oleh tanaman. Pada penelitian Segari et al. (2017) dosis pupuk yang diberikan dalam jumlah yang sesuai dengan kebutuhan tanaman akan memberikan pengaruh yang baik terhadap pertumbuhan. Pemberian pupuk yang berlebih akan memberikan efek keracunan, sedangkan pemberian pupuk yang kurang dari kebutuhan juga tidak akan memberikan pertumbuhan yang baik.

\section{KESIMPULAN}

Pemberian fermentasi urine kelinci dan air kelapa berpengaruh nyata terhadap jumlah akar. Perlakuan fermentasi urine kelinci dan air kelapa tidak berpengaruh nyata terhadap parameter tinggi tanaman, diameter batang, jumlah daun, panjang daun, warna daun, dan lebar daun. Perlakuan B (fermentasi urine kelinci 25\%) memberikan jumlah akar paling banyak (5,2 helai), tidak berbeda nyata dengan perlakuan A (kontrol) dan perlakuan $\mathrm{E}$ (fermentasi urine kelinci 25\% dan air kelapa 25\%), masing-masing memberikan jumlah akar sebesar 4,8 helai.

\section{UCAPAN TERIMA KASIH}

Penulis mengucapkan terima kasih kepada Kementerian Pendidikan, Kebudayaan, Riset, dan Teknologi Republik Indonesia/Badan Riset dan Inovasi Nasional yang telah mendanai peneltian ini.

\section{DAFTAR PUSTAKA}

Askal, M., \& Anton, R. P. (2015). Chemical composition, phytochemical and antioxidant activity from extract of Etlingera elatior flower from Indonesia. Jurnal of Pharmacognosy and Phytochemistry, 3(6), 233-238.

Choon, S. Y., \& Ding, P. (2017). Physiological changes of torch ginger (Etlingera elatior) in florescence during development. Hort. Science, 52(3), 479-482.

Djafar, T. A., Barus, A., \& Syukri. (2013). Respon pertumbuhan dan produksi sawi (Brassica juncea L.) terhadap pemberian urine kelinci dan pupuk guano. Jurnal Online Agroekoteknologi, 1(3), 23376597.

Dongoran, Y. R., \& Sularno. (2019). Efektivitas interval waktu pemberian air kelapa terhadap pertumbuhan bibit tanaman karet (Havea brasilliensis). Jurnal Agrosains dan Teknologi, 4(2), 2019.

Handayani, T., Sholihah, A., \& Asmaniyah, S. (2020). Pengaruh aplikasi pupuk kandang, NPK dan urine kelinci terhadap pertumbuhan dan produksi dua macam varietas tanaman mentimun (Cucumis sativus L). Jurnal Agronisma, 8(1), 12-21.

Kristina, P. N., \& Syahid, S. F. (2012). Pengaruh air kelapa terhadap multiplikasi tunasin vitro, produksi rimpang,dan kandung 
anxanthorrhizol temulawak di lapangan. Jurnal Littri, 18(3), 125134.

Maimulyanti, A., Prihadi, A. R. (2015). Chemical composition, phytochemical and antioxidant activity from extract of (Etlingera elatior) flower from Indonesia. Journal of Pharmacognosy and Phytochemistry, 3(6), 233-238.

Marini, \& Sitorus, H. (2019). Beberapa tanaman yang berpotensi sebagai repelen di Indonesia. J. Spirakel, 11 (1), 24-33.

Rosmala, A., Isnaeni, S., \& Permadi, D. (2020). Respon pertumbuhan dan keragaan warna tanaman honje aksesi Tasikmalaya terhadap perlakuan nutrisi hidroponik. Jurnal Agrosintesa, 3(1), 31-37.

Rosniawaty, S., Sudirja, R., \& Afrianto, H. (2015). Pemanfaatan urin kelinci dan urin sapi sebagai alternatif pupuk organik cair ada pembibitan kakao (Theobromacacao L.). Jurnal Kultivasi, 14 (1), 32-36.

Segari, A., Rianto, H., \& Susilowati, Y. E. (2017). Pengaruh macam media dan dosis urin kelinci terhadap hasil tanaman seledri (Apium graveolens L.). Jurnal Ilmu Pertanian Tropika dan Subtropika, 2 (1), 1 - 4.

Sembiring, M. Y., Setyobudi, L., \& Sugito, Y. (2017). Pengaruh dosis pupuk urin kelinci terhadap pertumbuhan dan hasil beberapa varietas tomat. Jurnal Produksi Tanaman, 5(1), 132-139.
Sukandar, D., Radiastuti, N., Muawanah, A., \& Hudaya, A. (2011). Antioxidant activity from water extract of kecombrang flower (Etlingera elatior). Jurnal Kimia Valensi, 2(2), 393-398.

Surachman, D. (2011). Teknik pemanfaatan. Jurnal Buletin Teknik Pertanian, 16 (1), 37-44.

Suryani, N., Nurjanah, D., \& Indriatmoko, D. D. (2019). Aktivitas antibakteri ekstrak batang kecombrang (Etlingera elatior (Jack) R.M.Sm.) terhadap bakteri plak gigi streptococcus mutans. Jurnal Kartika Kimia, 2(1), 23-29.

Syifa, T., Isnaeni, S., \& Rosmala, A. (2020). Pengaruh jenis pupuk anorganik terhadap pertumbuhan dan hasil tanaman sawi pagoda (Brassicaee narinosa L.). Jurnal Agroscript, 2 (1), 21-33.

Tan, J., Nagaraj, H., \& Srikumar, C. (2011). Antioxidant effects of Etlingera elatior peroxidation in rats. $B M C$ Research Notes. 4, 6-7.

Tiwery, R. R. (2014). Pengaruh penggunaan air kelapa (Cocos nucifera) terhadap pertumbuhan tanamn sawi (Brassica juncea L.). Jurnal Biopendix, 1 (1), 86-94. 